\title{
Kualitas Audit Berdasarkan Audit Tenure dan Ukuran Perusahaan Klien (Studi pada Perusahaan Manufaktur Sub Sektor Industri Dasar dan Kimia yang Terdaftar di Bursa Efek Indonesia Tahun 2015-2019)
}

\author{
Irfan Nursyaid Achlan Firdaus ${ }^{1}$, Dani Sopian ${ }^{2}$ \\ ${ }^{1,2}$ Program Studi Akuntansi \\ ${ }^{1,2}$ STIE STAN Indonesia Mandiri, Jl. Jakarta No. 79 Bandung \\ Email: irfannursyaid.a@gmail.com ${ }^{1}$, sopyan.dani@gmail.com ${ }^{2}$
}

\begin{abstract}
ABSTRAK
Penelitian ini bertujuan untuk mengetahui pengaruh audit tenure dan ukuran perusahaan klien terhadap kualitas audit pada perusahaan manufaktur sub sektor industri dasar dan kimia yang terdaftar di Bursa Efek Indonesia tahun 2015-2019. Penelitian ini berupa penelitian kuantitatif dengan populasi sebanyak 74 perusahaan, teknik pengambilan sampel menggunakan metode purposive sampling dan sampel pada penelitian ini sebanyak 37 perusahaan. Data yang digunakan dalam penelitian ini berupa data sekunder yang diperoleh melalui www.idx.co.id. Analisis data menggunakan analisis asosiatif metode regresi logistik untuk hipotesis audit tenure dan ukuran perusahan klien terhadap kualitas audit. Hasil penelitian dengan analisis regresi logistik menunjukkan bahwa audit tenure dan ukuran perusahaan klien secara simultan berpengaruh signifikan. Sedangkan secara parsial audit tenure berpengaruh positif tidak signifikan terhadap kualitas audit, dan ukuran perusahaan klien berpengaruh positif siginifikan terhadap kualitas audit.
\end{abstract}

Kata Kunci: Audit Tenure, Ukuran Perusahaan Klien, dan Kualitas Audit.

\begin{abstract}
This study aims to determine the effect of audit tenure and client company size on audit quality in basic industrial and chemical manufacturing companies listed on the Indonesia Stock Exchange in 2015-2019. This research is a quantitative study with a population of 74 companies, the sampling technique used is purposive sampling method and the samples in this study were 37 companies. The data used in this study are secondary data obtained through www.idx.co.id. Data analysis using associative analysis logistic regression method for audit tenure hypothesis and client company size on audit quality. The results of the research with logistic regression analysis showed that the simultaneous audit tenure and client company size had a significant effect. While partially audit tenure has a positive and insignificant effect on audit quality, and client firm size has a significant positive effect on audit quality.
\end{abstract}

Keywords: Audit Tenure, Client Company Size, and Audit Quality. 


\section{PENDAHULUAN}

Adanya kepercayaan yang besar dari pengguna laporan keuangan yang telah diaudit oleh auditor, mengharuskan auditor untuk menjaga kualitas audit yang dihasilkannya agar dapat dipertanggungjawabkan. Hasil kualitas audit dapat digunakan untuk menambah kredibilitas laporan keuangan bagi pengguna informasi, sehingga dapat mengurangi risiko informasi yang tidak kredibel. Oleh karena itu, kualitas audit sangat penting untuk menjaga kepercayaan publik terhadap keakuratan dan validitas laporan keuangan (Novrilia, Hariani., Fefri Indra Arza., 2019). Menurut Yadiati (2017:113) kualiatas audit adalah "Kualitas audit adalah ketepatan informasi yang dilaporkan auditor sesuai dengan standar audit yang digunakan auditor termasuk informasi pelanggaran akuntansi dalam laporan keuangan perusahaan klien”. Masih dalam buku yang sama (Yadiati, Winwin., 2017). "Kualitas audit merupakan fungsi dari kemampuan auditor untuk mendeteksi salah saji material (kemampuan teknis) dan melaporkan kesalahan (independensi audior)” (Agustini, T., 2020).

Kasus-kasus mengenai rendahnya kualitas audit sering terjadi pada era sekarang ini mau itu di luar negeri ataupun di dalam negeri, dan salah satu kasus kualitas audit ini seperti kasus KAP Tanubrata Sutanto Fahmi Bambang \& Rekan (Member of BDO Internasional) dengan PT. Garuda Indonesia Tbk dimana kementrian keuangan temukan dugaan laporan keuangan PT Garuda Indonesia tidak sesuai standar hal tersebut dikarenakan laporan keuangannya ditolak oleh dua Komisaris PT Garuda Indonesia. Pada akhirnya Otoritas Jasa Keuangan dan Kementrian Keuangan membuktikan bahwa terdapat skandal antara Akuntan Publik (AP) Kasner Sirumapea dan Kantor Akuntan Publik (KAP) Tanubrata, Sutanto, Fahmi, Bambang \& Rekan selaku auditor laporan keuangan PT Garuda Indonesia (Persero) (www.economy.okezone.com). Auditor dan KAP dalam menjalankan penugasan audit dilapangan sering mengahadapi banyak tekanan yang mungkin akan mempengaruhi kemampuannya dalam mengatasi suatu permasalahan. hal tersebut menandakan bahwa auditor dan KAP dalam menghasilkan kualitas audit tidak hanya dipengaruhi oleh faktor internal tetapi juga dipengaruhi oleh faktor eksternal.

Faktor pertama yaitu audit tenure. Audit tenure adalah lamanya hubungan antara auditor/KAP dengan kliennya dalam melakukan pekerjaan audit secara berturut-turut yang diukur berdasarkan jumlah tahunnya (Mgbame, C.O., Eragbhe, E., And Osazuwa, 
2012). (Rahmina, Listya Yuniastuti., 2014) mencatat bahwa kualitas audit berhubungan dengan audit tenure. Lamanya hubungan sangat mempengaruhi kualitas audit dikarenakam pihak auditor akan mengetahui kondisi dan karakteristik perusahaan yang sedang auditor periksa guna mempermudah mendeteksi dan melaporkan laporan auditornya. (Sirait, 2020) mengatakan lamanya hubungan audit tenure selama batas waktu perikatan, akan membuat auditor dan KAP semakin memahami perusahaan dan sistem akuntansi klien sehingga proses audit dapat berjalan dengan baik dan menghasilkan kualitas audit yang lebih baik. Tetapi hal tersebut tidak sejalan dengan Sulthon dan Cahyonowati, (2015) mengatakan bahwa semakin lama terjadi perikatan penugasan audit antara suatu KAP dengan klien maka akan menurunkan independensi dari kap tersebut karena perasaaan kekeluargaan yang membuat suatu KAP berkompromi mengenai hasil pelaporan auditnya.

Faktor eksternal kedua yang diduga mempengaruhi kualitas audit adalah ukuran perusahaan klien. Ukuran perusahaan menggambarkan besar kecilnya perusahaan. Besar kecilnya usaha tersebut ditinjau dari lapangan usaha yang dijalankan. Penentuan skala besar kecilnya perusahaan dapat ditentukan berdasarkan total penjualan, total aset, ratarata tingkat penjualan sehingga ukuran perusahaan dapat dihitung dengan (Seftianne, 2011). (Febriyanti, Ni Made Dewi., 2014) mengatakan Ukuran perusahaan besar memiliki system pengendalian internal yang lebih baik dibandingkan perusahaan kecil. Hal ini membuktikan bahwa dengan pengendalian internal yang baik akan meningkatkan kualitas audit, seiring dengan mudahnya auditor untuk mendapatkan informasi yang dibutuhkannya. Begitu pula sebaliknya dengan pengendalian internal yang lemah, maka kualitas audit akan menurun, karena auditor harus bekerja dengan lebih keras. Hal tersebut tidak sejalan dengan (Hasanah, Ade Nahdiatul., 2018) bahwa ukuran perusahaan besar belum tentu memiliki manajemen yang baik dalam mengelola dan pengendalian intern dan tidak menjadikan ukuran perusahaan salah satu unsur yang berdampak buruk terhadap kualitas audit.

Penelitian ini dilakukan pada perusahaan manufaktur sub sektor industri dasar dan kimia yang terdaftar di Bursa Efek Indonesia periode 2015-2019. Menurut peneliti sektor industri dasar dan kimia mempunyai peran penting juga bagi masyarakat dan kegiatan ekonomi yang ada di dalam negeri maupun di luar negeri, dan pada sektor ini juga mempunyai tanggungjawab agar tidak terjadi penyimpangan serta menjaga 
kestabilan pertumbuhan ekonomi. Berdasarkan uraian di atas, peneliti tertarik dan termotivasi melakukan penelitian untuk mengetahui dan mengkaji ulang pengaruh audit tenure dan ukuran perusahaan klien terhadap kualitas audit.

\section{Pengaruh Audit Tenure Terhadap Kualitas Audit}

Audit tenure adalah masa perikatan KAP atau auditor dan klien terkait jasa audit yang disepakati sebagai jangka waktu hubungan kerjasama. Tenure menjadi salah satu perdebatan yang mempengaruhi kualitas audit. Pada saat tenure audit yang dilakukan secara singkat dan tenure audit yang dilakukan dalam jangka waktu lama. Keterlibatan tahun pertama audit (masa tenure pendek) dianggap kurang menyeluruh (kurang mendalam), karena hal ini membutuhkan beberapa waktu untuk mengidentifikasi semua resiko audit potensial untuk klien baru, sehingga akan mengurangi kualitas audit. Sedangkan masa tenure panjang yang (excerssive long tenure) akan dikaitkan dengan kualitas audit yang baik, karena auditor yang ada pada KAP akan lebih memahami, menguasai dan memilki pengetahuan yang lebih terhadap kriteria perusahaan yang di auditnya. Lamanya hubungan audit tenure antara KAP dengan klien selama batas waktu perikatan, tidak akan menganggu sikap independensi seorang auditor atau KAP, maka KAP tersebut akan semakin memahami perusahaan dan sistem akuntansi klien sehingga proses audit dapat berjalan dengan baik. Oleh karena itu, dengan diberlakukannya peraturan mengenai pembatasan masa perikatan yang diberlakukan oleh Menteri Keuangan dianggap mampu menjadi solusi untuk menghindari kecurangan antara KAP dan kliennya Dengan demikian dapat ditarik kesimpulan bahwa pengaruh audit tenure terhadap kualitas audit ini berpengaruh positif dimana semakin lama masa perikatan (audit tenure) antara KAP dengan klien (perusahaan) akan meningkatkan kualitas audit.

\section{Pengaruh Ukuran Perushaan Klien Terhadap Kualitas Audit}

Seiring dengan ukuran peusahaan yang selalu mengalami peningkatan dalam setiap periodenya, Semakin besar ukuran perusahaan maka akan semakin meningkat pula agency cost yang terjadi. Pada perusahaan kecil, kepercayaan pengguna laporan keuangan dianggap mampu mempromosikan investasi mereka dan dapat menjadikan perusahaan tersebut lebih dikenal publik dan investor. Sedangkan pada perusahaan besar yang sudah mendapatkan banyak perhatian dari publik dan investor harus mampu 
menjaga reputasi perusahaan mereka dengan menggunakan jasa KAP besar yang independent dan professional untuk meningkatkan kredibilitas laporan keuangan yang akan digunkan oleh pihak eksternal. Selain itu ukuran perusahaan berpengaruh terhadap kualitas audit yang berarti perusahaan berukuran besar memiliki kompleksitas operasi dan peningkatan pemisahan antara manajemen dan pemegang saham, sangat memerlukan KAP yang dapat mengurangi agency cost. Selain itu, jumlah konflik agensi yang meningkat menyebabkan permintaan untuk membedakan kualitas auditor juga meningkat. Oleh karena itu, perusahaan berukuran besar pastinya akan lebih memilih menggunakan jasa KAP berukuran besar untuk menghasilkan laporan audit yang berkualitas. Ukuran perusahaan besar memiliki system pengendalian internal yang lebih baik dibandingkan perusahaan kecil. Hal ini membuktikan bahwa dengan pengendalian internal yang baik akan meningkatkan kualitas audit, seiring dengan mudahnya auditor untuk mendapatkan informasi yang dibutuhkannya. Begitu pula sebaliknya dengan pengendalian internal yang lemah, maka kualitas audit akan menurun, karena auditor harus bekerja dengan lebih keras. Dengan demikian dapat ditarik kesimpulan bahwa pengaruh ukuran perusahaan klien berpengaruh positif terhadap kualitas audit, dimana semakin besar perusahaan klien maka akan dapat meningkatkan kualitas laporan audit yang dihasilkan oleh auditor.

\section{Model Analisis}

Berdasarkan kerangka teoritis di atas, maka dapat di kemukakan model analisis Seperti pada gambar berikut ini:

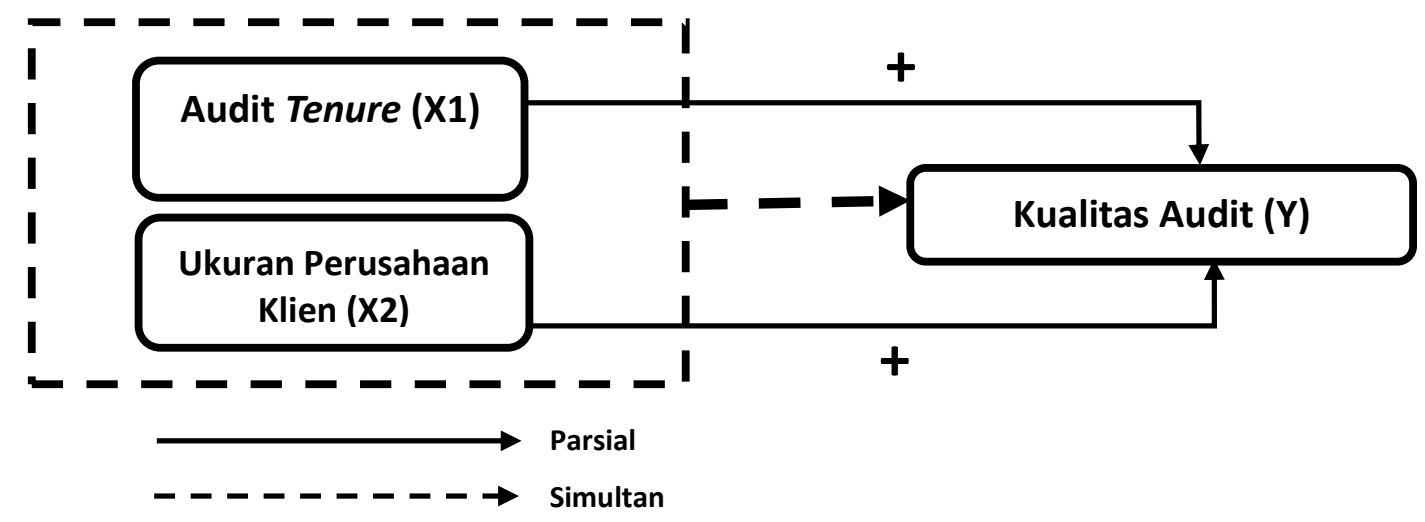

Gambar 1: Model Analisis 


\section{Hipotesis}

Berdasarkan kerangka pemikiran yang telah dikemukakan diatas, maka hipotesis dalam penelitian ini adalah sebagai berikut:

H1 : Terdapat pengaruh positif signifikan audit tenure terhadap kualitas audit.

H2 : Terdapat pengaruh positif signifikan ukuran perusahaan klien terhadap kualitas audit.

\section{METODE PENELITIAN}

Populasi dan sampel dalam penelitian ini yaitu perusahaan manufaktur sektor industri dasar dan kimia yang terdaftar pada Bursa Efek Indonesia (BEI) selama periode 2015-2019. Pengambilan sampel dan penentuan ukuran sampel dalam penelitian ini dilakukan dengan metode purposive sampling. Purposive sampling adalah teknik penentuan sampel dengan pertimbangan tertentu (Sugiyono, 2017). Kriteria-kriteria yang digunakan adalah:

1. Perusahaan manufaktur Sektor industri dasar dan kimia yang terdaftar di Bursa efek Indonesia (BEI) pada periode 2015-2019.

2. Perusahaan manufaktur sektor industri dasar dan kimia yang tidak menerbitkan laporan tahunan (Annual Report) dan laporan keuangan yang telah diaudit oleh auditor independen dalam periode 2015-2019.

3. Perusahaan manufaktur sektor industri dasar dan kimia yang telah menerbitkan Laporan tahunan (Annual Report) dan Laporan Keuangan yang telah diaudit oleh auditor independent selama tahun penelitian serta memiliki data terkait variabel penelitian yang dapat diakses melalui website BEI (www.idx.co.id) (www.sahamok.com) dan serta situs situs resmi perusahaan terkait. 
Tabel 1. Rekapitulasi Sampel Penelitian

\begin{tabular}{clc}
\hline No & \multicolumn{1}{c}{ Keterangan } & Jumlah \\
\hline 1 & $\begin{array}{l}\text { Seluruh perusahaan manufaktur sektor industri dasar } \\
\text { dan kimia yang terdaftar di BEI Selama tahun } \\
\text { penelitian yaitu 2015-2019 }\end{array}$ & 74 \\
\hline 2 & $\begin{array}{l}\text { Perusahaan manufaktur sektor industri dasar dan } \\
\text { kimia yang baru tercatat selama tahun 2015-2019 }\end{array}$ & -7 \\
\hline 3 & $\begin{array}{l}\text { Perusahaan yang tidak mensajikan annual report } \\
\text { dan laporan audit secara lengkap pada periode 2015- }\end{array}$ & -23 \\
& 2019 & -7 \\
\hline 4 & Perusahaan sampel data outlier & 37 \\
\hline 5 & Perusahaan yang menjadi sampel penelitian & 5 \\
\hline 6 & Tahun penelitian 2015-2019 & 185 \\
\hline 7 & Total unit analisis & \\
\hline
\end{tabular}

Sumber: Bursa Efek Indonesia, Data diolah peneliti, Juli (2020)

\section{Operasionalisasi Variabel}

Menurut (Sugiyono, 2017) variabel dependen adalah variabel yang dipengaruhi atau yang menjadi akibat karena adanya variabel bebas. Dalam penelitian ini yang menjadi variabel dependenya adalah kualitas audit dengan symbol (Y). Proksi terhadap kualitas audit pada penelitian ini diukur dengan ukuran KAP Big Four dan Non-Big Four. Dewi dan Jati (2014) dalam Abdillah dan Nurhasanah (2020) mengatakan pengukuran kualitas audit Kap Big Four dan Non-Big Four menggunakan variabel dummy, yaitu diberi nilai 1 untuk KAP Big Four dan diberi nilai 0 untuk KAP Non Big Four. Kantor akuntan publik di Indonesia yang termasuk dalam kategori KAP the big four di Indonesia adalah:

1. KAP Purwantono, Sungkoro \& Surja berafiliasi dengan Ernst \& Young (EY).

2. KAP Satrio Bing Eny\& Rekan berafiliasi dengan Deloitte Touche Tohmatsu (Deloitte).

3. KAP Siddharta dan Widjaja berafiliasi dengan Klynveld Peat Marwick Goerdeler (KPMG).

4. KAP Tanudireja Wibisana dan Rekan berafiliasi dengan Pricewaterhouse Coopers (PWC).

\begin{aligned} \hline Kualitas Audit = & (1) jika diaudit oleh KAP yang berafiliasi dengan KAP \\ & Big Four, dan (0) jika tidak diaudit oleh KAP yang \\ & berafiliasi dengan KAP Big Four. \end{aligned}


Menurut (Sugiyono, 2017) mendefinisikan variabel independen adalah variabel yang mempengaruhi atau yang menjadi sebab perubahannya atau timbulnya variabel dependen. Dalam penelitian ini yang termasuk variabel independen adalah :

Sebagai variabel independen pertama yaitu audit tenure dimana diukur dengan menghitung jumlah tahun lamanya perikatan antara KAP dengan klien (perusahaan). Tahun pertama perikatan dimulai dengan angka 1 dan ditambah satu untuk tahun-tahun berikutnya jika masih menggunakan KAP yang sama dan kembali lagi ke angka 1 jika perusahaan melakukan pergantian KAP.

\section{Audit Tenure $\quad=$ Jumlah tahun perikatan antara KAP dan Klien}

Sebagai variabel independen kedua yaitu ukuran perusahaan klien dimana pengukuran terhadap ukuran perusahaan klien diproksikan dengan nilai logaritma total asset dengan tujuan untuk menghaluskan besarnya angka dan menyamakan ukuran saat regresi. Dalam penelitian ini ukuran perusahaan disimbolkan dengan LN ASSETS.

Ukuran Perusahaan Klien $=$ Ln Total Asset

\section{Analisis Asosiatif}

Analisis Asosiatif merupakan salah satu teknik analisis data dalam penelitian kuantitatif. Analisis Asosiatif digunakan untuk menganalisis hubungan atau pengaruh antara dua variabel atau lebih. Analisis assosiatif dalam penelitian ini menggunakan metode regresi logistik. Analisis Asosiatif ini dilakukan dengan menggunakan tingkat signifikansi $0,05(\alpha=5 \%)$ dan penetapan hipotesisnya yaitu Hipotesis nol (Ho) menyatakkan hipotesis ditolak sedangkan hipotesis alternatif (Ha) menyatakan Hipotesis diterima.

Tahapan pertama uji asumsi dasar dalam model analisis regresi logistic menurut (Ghozali) adalah sebagai berikut:

1. Menilai Kelayakan Model Regresi (Goodness of Fit Test)

$\mathrm{H}_{0}$ : Jika nilai sig Hosmer and Lemeshow's Goodness of Fit Test $(\leq)$ 0,05 artinya ada perbedaan antara model dengan data

Ha : Jika nilai sig Hosmer and Lemeshow's Goodness of Fit Test (>) 0,05Tidak ada perbedaan antara model dengan data 
2. Menilai Keseluruhan Model (Overall Model Fit)

$\mathrm{H}_{0}$ : Jika nilai -2 log likehood awal (Block number $\left.=0\right)<$ nilai -2 log likehood akhir (Block number=1). Artinya model yang dihipotesiskan tidak fit dengan data

Ha : Jika nilai -2 log likehood awal (Block number $=0)>$ nilai -2 log likehood akhir (Block number=1). Artinya model yang dihipotesiskan fit dengan data.

Selanjutnya dilakukan pengujian Pengujian koefisien regresi dilakukan untuk menguji seberapa jauh semua variabel independen yang dimasukkan dalam model mempunyai pengaruh terhadap hasil kualitas audit. Koefisien regresi logistik dapat ditentukan dengan menggunakan p-value (probability value). Tingkat signifikansi $(\alpha)$ yang digunakan sebesar $5 \%$. Kriteria penerimaan dan penolakan hipotesis alternative didasarkan pada signifikansi p-value. Jika p-value $>\alpha$, maka hipotesis alternative ditolak. Sebaliknya jika p-value $<\alpha$, maka alternatif diterima. Adapun model regresi logistik yang dapat dibentuk adalah sebagai berikut:

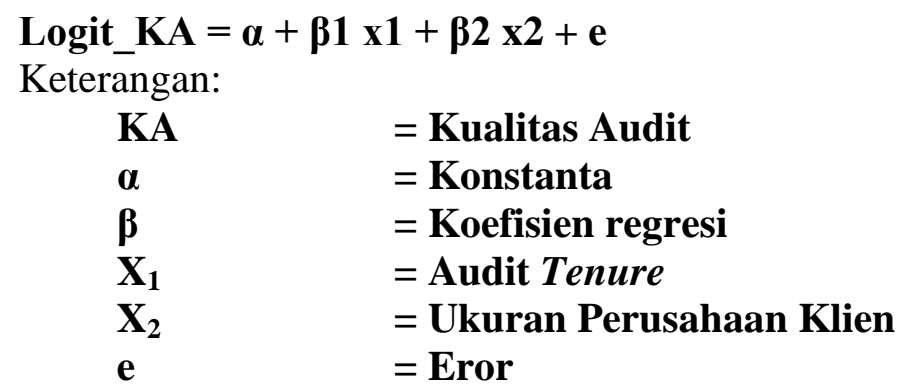

Pengujian signifikansi pada regresi logistik dapat dibagi menjadi dua yaitu pengujian secara simultan dan pengujian secara parsial. Pengujian secara individual atau parsial dapat dilakukan dengan Uji Wald. Sedangkan pengujian secara simultan atau serentak dilakukan dengan menggunakan Omnibus Test of Model Coefficients.

1. Uji hipotesis secara simultan dalam analisis regresi logistik menggunakan Omnibus Test of Model Coefficients (Ghozali, 2018). Variabel independen dalam penelitian ini akan diuji bersama guna mengetahui apakah semua variabel independen secara serentak mampu mempengaruhi variabel dependen. Adapun tingkat signifikasinya sebesar 5\% atau 0,05 yang dapat dijelaskan sebagai berikut: 
Ho : Jika nilai signifikansi $\geq 0,05$, Maka Ho diterima dan Ha ditolak yang berarti (audit tenure dan ukuran perusahaan klien) secara simultan berpengaruh tidak signifikan terhadap variabel dependen (kualitas audit).

Ha : Jika nilai signifikansi $<0,05$, Maka Ha diterima dan Ho ditolak yang berarti variabel independen (audit tenure dan ukuran perusahaan klien) secara simultan berpengaruh signifikan terhadap variabel dependen (kualitas audit).

2. Uji secara parsial dalam regresi logistik dapat dilakukan menggunakan uji wald (Ghozali, 2018). Uji stasistik Wald ini dapat ditentukan dengan berdasarkan pada nilai $\beta$ (beta koefisien) dan signifikan $p$-value (probability value) dibandingkan dengan tingkat signifikan (a) sebagai berikut :

Ho: Jika $\beta>0$ dan $(p$-value $) \geq 0,05$, maka terdapat pengaruh positif tidak signifikan antar variabel independen terhadap variabel dependen.

Ha: Jika $\beta>0$ dan ( $p$-value) $<0,05$, maka terdapat pengaruh positif dan signifikan antar variabel independen terhadap variabel dependen.

3. Koefisien Determinasi (Nagelkerke $R$ Square)

Variabilitas dari variabel independen dalam menjelaskan variabel dependen diukur menggunakan koefisien determinasi yang dapat dilihat dari nilai Nagelkerke $R$ Square. Nagelkerke $R$ Square merupakan nilai dari kemampuan variabel independen yang mampu menjelaskan variabilitas dari variabel dependen sedangkan sisanya dapat dijelaskan oleh variabel-variabel lain diluar dari model penelitian ini. Nilai dari Nagelkerke $R$ Square berupa desimal yang dapat diubah menjadi presentase agar mudah dipahami dan diintrepretasikan (Ghozali, 2018).

\section{HASIL DAN PEMBAHASAN}

Tabel 2. Hosmer and Lemeshow Test

\begin{tabular}{ccccc}
\hline Step & Chi-square & Df & \multicolumn{2}{c}{ Sig. } \\
\hline & 1 & 14,051 & 8 &, 080 \\
\hline
\end{tabular}

Sumber: Output SPPS IBM 25, Data diolah peneliti (2020).

Berdasarkan tabel 4.1 menunjukan bahwa nilai Chi-square sebesar 14,051 dengan nilai sig sebesar 0,080 dapat disimpulkan Hipotesis alternatif (Ha) diterima. Hal ini dibuktikan dengan nilai sig hosmer and lemeshow tes sebesar $0.080>0.05$ yang berarti bahwa menandakan tidak ada perbedaan antara model dengan data atau terdapat 
kesesuaian antara data sampel dengan model regresi yang digunakan karena model mampu memprediksi nilai observasinya.

Tabel 3. Overall Model Fit

\begin{tabular}{cc}
\hline -2 Log Likelihood Block Number $=0$ & -2 Log Likelihood Block Number $=1$ \\
\hline 256,416 & 229,041
\end{tabular}

Sumber: Output SPPS IBM 25, Data diolah peneliti (2020).

Berdasarkan tabel 4.2 menunjukan bahwa nilai pada -2 Log Likelihood (Block Number $=0$ ) sebesar 256,416 dan nilai -2 Log Likelihood (Block Number $=1$ ) sebesar 229,041 menunjukkan adanya penurunan pada nilai -2 Log Likelihood sebesar 27,375 atau dengan kata lain nilai pada -2 Log Likelihood (Block Number $=0$ ) lebih besar $(>)$ dari pada nilai -2 Log Likelihood (Block Number = 1) artinya hipotesis alternatif (Ha) diterima. maka penurunan pada nilai -2 Log Likelihood ini menandakan bahwa ketika penambahan dua variabel independen kedalam model regresi menunjukkan model regresi yang lebih baik atau model yang dihipotesiskan fit dengan data. tabel 4.14 sebagai berikut :

Tabel 4. Variables in the Equation

\begin{tabular}{|c|c|c|c|c|c|c|c|}
\hline & & $B$ & S.E. & Wald & $D f$ & Sig. & $\operatorname{Exp}(B)$ \\
\hline \multirow[t]{6}{*}{ Step $1^{\mathrm{a}}$} & Audit & & & & & & \\
\hline & Tenure & , 109 &, 116 & ,888 & 1 & ,346 & 1,115 \\
\hline & Ukuran & & & & & & \\
\hline & Perusahaan & & & & & & \\
\hline & Klien & 1,799 & ,387 & 21,609 & 1 &, 000 & 6,041 \\
\hline & Constant & $-22,884$ & 4,872 & 22,067 & 1 &, 000 &, 000 \\
\hline
\end{tabular}

Sumber: Output SPPS IBM 25, Data diolah peneliti (2020).

Dari pengujian persamaan regresi logistik yang disajikan pada tabel 4.3 tersebut, maka diperoleh model regresi logit sebagai berikut :

Logit_KA $=\alpha+\beta 1 \times 1+\beta 2 \times 2+e$

Logit_KA $=-22,884+0,109 \times 1+1,799$ X2 + 0,05

Berdasarkan persamaan garis regresi logit yang terbentuk dan nilai-nilai dari koefisien regresi masing-masing variabel bebas, maka besarnya nilai dari intercept dan nilai koefisien dari variabel bebas dapat diinterprestasikan. Interpretasi yang tepat untuk koefisien ini tentunya tergantung pada kemampuan menempatkan arti dari 
perbedaan antara dua logit. Oleh karenanya, dalam regresi logistik, pengukuran koefisien regresi logit menggunakan ukuran yang dikenal dengan nama odds ratio atau Exp (B). Dari hasil perhitungan analisis regresi maka interprestasi koefisien regresi dapat dijelaskan sebagai berikut:

1. Nilai intercept persamaan regresi diatas adalah sebesar $-22,884$ dengan nilai odds ratio sebesar 0,000. Artinya ketika semua variabel independen bernilai 0 peluang perusahaan mendapatkan audit yang berkualitas adalah sebesar 0,000 atau tidak berpeluang mendapatkan audit yang berkualitas.

2. Nilai koefisien regresi variabel audit tenure adalah sebesar 0,109 dengan nilai odds ratio sebesar 1,115. Hal ini berarti apabila audit tenure meningkat 1 satuan maka peluang perusahaan perusahaan mendapatkan audit yang berkualitas akan meningkat sebesar 1,115 dengan asumsi variabel bebas lainnya dianggap konstan.

3. Nilai koefisien regresi variabel ukuran perusahaan klien adalah sebesar 1,799 dengan nilai odds ratio sebesar 6,041. Hal ini berarti apabila ukuran perusahaan klien meningkat 1 satuan maka peluang perusahaan perusahaan mendapatkan audit yang berkualitas akan meningkat sebesar 6,041 dengan asumsi variabel bebas lainnya dianggap konstan.

Tabel 5. Omnibus Tests of Model Coeffiencients

\begin{tabular}{lcccr}
\hline & & Chi-square & $\boldsymbol{d}$ f & \multicolumn{1}{c}{ Sig. } \\
\hline Step 1 & Step & 27,856 & 2 &, 000 \\
\cline { 2 - 5 } & Block & 27,856 & 2 &, 000 \\
\cline { 2 - 5 } & Model & 27,856 & 2 &, 000 \\
\hline
\end{tabular}

Sumber: Output SPPS IBM 25, Data diolah peneliti (2020).

Berdasarkan tabel 4.4 Omnibus Tests of Model Coeffiencients dapat dijelaskan bahwa Audit Tenure (X1) dan variabel Ukuran Perusahaan Klien (X2) memiliki nilai chi-square yaitu sebesar 27,856. Berdasarkan uji simultan (Omnibus Tests of Model Coeffiencients), maka diperoleh nilai signifikan kedua variabel tersebut sebesar 0,000 yang berarti secara bersamaan audit tenure dan ukuran perusahaan klien mempengaruhi kualitas audit. Hal tersebut dibuktikan dengan nilai signifikan $0,000<0,05$ yang artinya Ha diterima dan Ho ditolak, maka variabel independen secara simultan berpengaruh signifikan terhadap variabel dependen. 
Tabel 6. Variables in the Equation (Wald)

\begin{tabular}{llrrrrrr}
\hline & & $\boldsymbol{B}$ & S.E. & Wald & Df & Sig. & $\boldsymbol{E x p}(\boldsymbol{B})$ \\
\hline Step $1^{\text {a }}$ & Audit & & & & & & \\
& \begin{tabular}{l} 
Tenure \\
\cline { 2 - 7 }
\end{tabular} &, 109 &, 116 &, 888 & 1 &, 346 & 1,115 \\
\hline $\begin{array}{l}\text { Ukuran } \\
\text { Perusahaan }\end{array}$ & & & & & & \\
Klien & 1,799 &, 387 & 21,609 & 1 &, 000 & 6,041 \\
\hline & Constant & $-22,884$ & 4,872 & 22,067 & 1 &, 000 &, 000 \\
\hline
\end{tabular}

Sumber: Output SPPS IBM 25, Data diolah peneliti (2020).

Berdasarkan tabel 4.5 dapat disimpulkan sebagai berikut:

1. Pengujian Hipotesis Pertama, pengujian terhadap hipotesis pertama dilakukan melalui pengujian signifikansi koefisien regresi dari variabel audit tenure. Hipotesis pertama penelitian ini menyatakan bahwa audit tenure berpengaruh positif dan signifikan terhadap kualitas audit. Nilai koefisien regresi variabel audit tenure adalah 0,109 yang memilki arti berpengaruh positif terhadap kualitas audit. Sedangkan nilai signifikan sebesar 0,346 pada tingkat signifikansi $\alpha=5 \%$, artinya koefisien regresi tersebut tidak signifikan karena nilai signifikansi 0,424 > 0,05, maka dapat disimpulkan bahwa nilai $\beta>0$ dan nilai signifikansi ( $p$-value $) \geq 0,05$, (Ha1 ditolak) artinya audit tenure terdapat pengaruh positif tidak signifikan atau (tidak terdapat pengaruh yang signifikan) terhadap kualitas audit sehingga Ha1 tidak dapat didukung.

2. Pengujian Hipotesis Kedua, Pengujian terhadap hipotesis kedua dilakukan melalui pengujian signifikansi koefisien regresi dari variabel ukuran perusahaan klien. Hipotesis kedua penelitian ini menyatakan bahwa ukuran perusahaan klien berpengaruh positif dan signifikan terhadap kualitas audit. Nilai koefisien regresi variabel ukuran perusahaan klien sebesar 1,799 yang memilki arti berpengaruh positif terhadap kualitas audit. Sedangkan nilai signifikan sebersar 0.000 pada tingkat signifikansi $\alpha=5 \%$, artinya koefisien regresi tersebut signifikan karena nilai signifikansi $0,000<0,05$, maka dapat disimpulkan bahwa nilai $\beta>0$ dan nilai signifikansi (p-value $)<0,05$, (Ha2 diterima) artinya ukuran perusahaan klien berpengaruh positif dan signifikan terhadap kualitas audit sehingga $\mathrm{Ha} 2$ dapat didukung.

3. 
Tabel 7.1 Model Summary

\begin{tabular}{crrr}
\hline Step & -2 Log likelihood & $\begin{array}{c}\text { Cox \& Snell } \\
\boldsymbol{R} \text { Square }\end{array}$ & $\begin{array}{c}\text { Nagelkerke } \\
\boldsymbol{R} \text { Square }\end{array}$ \\
\hline 1 & $228,560^{\mathrm{a}}$ &, 140 &, 186 \\
\hline
\end{tabular}

Sumber: Output SPPS IBM 25, Data diolah peneliti (2020).

Hasil model summary pada tabel 4.17 memberikan nilai Nagelkerke $R$ Square sebesar 0.186. Hal ini berarti variabilitas variabel dependen yang dapat dijelaskan oleh variabilitas variabel independen hanya sebesar $18.6 \%$ sedangkan sisanya sebesar $81,4 \%$ dijelaskan oleh variabel lain yang tidak digunakan dalam penelitian ini.

\section{Pembahasan}

\section{Pengaruh Audit Tenure Dan Ukuran Perusahaan Klien Terhadap Kualitas Audit}

Dalam penelitian ini yaitu audit tenure dengn proksi jumlah tahun perikatan KAP dengan perusahaan, dan ukuran perusahaan klien dengan proksi total asset perusahaan yang dirubah dengan Logaritma Natural (LN) secara simultan dengan menggunakan uji Omnibus Test of Model Coefficients menunjukan bahwa secara bersama-sama variabel independen memiliki pengaruh signifikan terhadap variabel dependen. Hal ini dapat dibuktikan dibuktikan dengan nilai signifikan $<\alpha$, atau dapat dikatakan bahwa variabel yang meliputi audit tenure dan ukuran perusahaan klien secara bersama-sama berpengaruh signifikan terhadap kualitas audit.

\section{Pengaruh Audit Tenure Terhadap Kualitas Audit}

Hipotesis kesatu atau Ha1 yang memprediksi adanya pengaruh positif dan signifikan antara audit tenure dengan proksi lamanya jumlah tahun perikatan KAP dengan perusahaan. Namun hasil penelitian ini ternyata audit tenure berpengaruh positif tidak signifikan atau tidak berpengaruh signifikan terhadap kualitas audit maka dapat dijelaskan bahwa semakin lama masa perikatan antara KAP dengan klien hal ini dapat memperbaiki atau meningkatkan kualitas audit tetapi meskipun begitu pengaruh tersebut tidak begitu berarti atau tidak memberikan dampak yang signifikan (pengaruh ini akan terlihat dalam jangka waktu yang sangat panjang). Adanya penolakan atas hipotesis ini dikarenakan audit tenure bukan patokan bahwa hasil audit akan berkualitas. Lamanya masa perikatan audit seharusnya Kantor Akuntan Publik lebih mengerti kondisi dan kriteria perusahaan klien sehingga tau jika klien ingin memanipulasi 
laporan keuangan, disisi lain hubungan yang terlalu lama antara auditor atau KAP dengan klien akan berpotensi terjalinya hubungan emosional, saat terjalinnya hubungan emosional antara KAP dengan klien yang akan berdampak pada kepuasan terhadap pihak klien karena KAP merasa percaya terhadap klien dan bisa saja KAP akan menuruti apa keinginan klien, dan pada akhirnya tidak ada penyesuaian dalam prosedur audit yang dijalankan oleh auditor pada KAP tersebut untuk mencerminkan perubahan bisnis dan resiko yang terkait pada perusahaan klien yang akan disampaikan pada laporan audit, sehingga pada akhirnya auditor menjadi tidak professional dalam mengumpulkan bukti audit mereka, hal ini sudah jelas akan menurunkan kualitas audit yang dihasilkan.

Hasil penelitian ini mendukung hasil peneltian yang di lakukan oleh penelitian (Febriyanti, Ni Made Dewi., 2014); (Yolanda, Stephanie., Fefri Indra Arza, 2019); dan (Fauziyyah, Zahra Ismi., 2020) menyatakan bahwa audit tenure tidak berpengaruh signifikan terhadap kualitas audit. Sedangkan hasil penelitian ini membantah hasil penelitian yang dilakukan oleh (Andrian, Ria Rizky., 2017) dan (Purnomo, Listiya Ike, 2019) yang menyatakan bahwa audit tenure berpengaruh positif dan signifikan terhadap kualitas audit.

\section{Pengaruh Ukuran Perusahaan Klien Terhadap Kualitas Audit}

Hipotesis kedua atau $\mathrm{Ha} 2$ yang memprediksi adanya pengaruh positif dan signifikan antara ukuran perusahaan klien yang diproksikan dengan total asset perusahaan dirubah menjadi Logaritma Natural (Ln). Hasil penelitian ini ternyata ukuran perusahaan klien berpengaruh positif dan signifikan terhadap kualitas audit maka dapat dijelaskan bahwa semakin besar ukuran perusahaan memperbaiki atau meningkatkan kualitas audit yang dihasilkan oleh auditor karena sistem pengendalian internal pada perusahaan yang berukuran besar cenderung lebih baik dan lebih efektif dibanding perusahaan yang berukuran kecil. Dengan internal control system yang baik akan memudahkan auditor dalam mendapatkan informasi yang dibutuhkannya dan pastinya akan meningkatkan kualitas audit yang dihasilkan oleh auditor. Selain itu ukuran perusahaan berpengaruh terhadap kualitas audit yang berarti perusahaan berukuran besar memiliki kompleksitas operasi dan peningkatan pemisahan antara manajemen dan pemegang saham, sangat memerlukan KAP yang dapat mengurangi agency cost. Selain itu, jumlah konflik agensi yang meningkat menyebabkan permintaan 
untuk membedakan kualitas auditor juga meningkat. Oleh karena itu, perusahaan berukuran besar pastinya akan lebih memilih menggunakan jasa KAP berukuran besar untuk menghasilkan laporan audit yang berkualitas.

Hasil penelitian ini sejalan dengan hasil peneltian yang di lakukan oleh (Febriyanti, Ni Made Dewi., 2014); (Udayanti, Ni Kadek Sri., 2017); (Oentoro, Vannesa Paramitha, 2019); dan (Buchori, Ahmad., 2019) menyatakan bahwa ukuran perusahaan klien berpengaruh positif dan signifikan terhadap kualitas audit. Sedangkan hasil penelitian ini tidak sejalan dengan hasil penelitian yang dilakukan oleh (Andrian, Ria Rizky., 2017) dan (Hasanah, Ade Nahdiatul., 2018) yang menyatakan ukuran perusahaan tidak berpengaruh terhadap kualitas audit.

\section{KESIMPULAN}

Penelitian ini bertujuan untuk menguji pengaruh audit tenure dan ukuran perusahaan klien terhadap kualitas audit pada perusahaan manufaktur sub sektor industri dasar dan kimia yang terdaftar di Bursa Efek Indonesia tahun 2015-2019. Penelitian ini dilakukan terhadap laporan keuangan dan laporan auditor independen yang mencakup 37 sampel perusahaan penelitian dengan runtun waktu sebanyak 5 tahun sehingga unit data yang diolah sebanyak 185 observasi, maka peneliti mengambil kesimpulan sebagai berikut :

1. Secara simultan audit tenure dan ukuran perusahaan klien berpengaruh dan signifikan terhadap kualitas audit pada perusahaan manufaktur sub sektor industri dasar dan kimia yang terdaftar di Bursa Efek Indonesia tahun 2015-2019.

2. Secara parsial audit tenure berpengaruh positif tidak signifikan terhadap kualitas audit. Hal ini menunjukan bahwa semakin lama masa perikatan antara KAP dengan klien hal ini dapat memperbaiki atau meningkatkan kualitas audit tetapi meskipun begitu pengaruh tersebut tidak begitu berarti atau tidak memberikan dampak yang signifikan.

3. Secara parsial ukuran perusahaan klien berpengaruh positif signifikan terhadap kualitas audit. Hal ini menunjukkan bahwa semakin besar ukuran perusahaan akan memperbaiki atau meningkatkan kualitas audit. 


\section{DAFTAR PUSTAKA}

Agustini, T., A. D. L. S. (2020). Pengaruh Fee Audit, Audit Tenure dan Rotasi Audit Terhadap Kualitas Audit Di Bursa Efek Indonesia. Jurnal EMBA, 8(1), 637-646.

Andrian, Ria Rizky., A. N. (2017). Pengaruh Audit Tenure, Rotasi KAP, Ukuran Perusahaan, dan Ukuran Kap Terhadap Kualitas Audit. Seminar Nasional Dan The 4th Call for Syariah Paper, ISSN 2460-.

Buchori, Ahmad., A. H. B. (2019). Pengaruh Ukuran Perusahaan Klien, Audit Tenure dan Spesialisasi Auditor Terhadap Kualitas Audit. Jurnal Pajak, Akuntansi, Sistem Informasi, Dan Auditing, 1(1), 22-39.

Fauziyyah, Zahra Ismi., A. P. (2020). Pengaruh Audit Fee,Audit Tenure, dan Rotasi Audit terhadap Kualitas Audit. Jurnal Monex, 9(1).

Febriyanti, Ni Made Dewi., A. I. M. M. (2014). Pengaruh Masa Perikatan Audit, Rotasi Kap, Ukuran Perusahaan Klien, dan Ukuran KAP Pada Kualitas Audit. E-Jurnal Akuntansi Universitas Udayana, 7(2), 503-518.

Ghozali, I. (2018). Aplikasi Analisis Multivariate Dengan Program IBM SPSS 25. Semarang.

Hasanah, Ade Nahdiatul., A. M. S. P. (2018). Pengaruh Ukuran Perusahaan, Audit Tenure Terhadap Kualitas Audit. Jurnal Akuntansi, 5(1), P-ISSN 2339-2436. EISSN 2549-5968.

Mgbame, C.O., Eragbhe, E., And Osazuwa, N. (2012). Audit Partner and Audit Quality: An Emprical Analysis. European Journal of Business and Management, 4(7), 154-159.

Novrilia, Hariani., Fefri Indra Arza., A. V. F. S. (2019). Pengaruh Fee Audit, Audit Tenure, Dan Reputasi KAP Terhadap Kualitas Audit (Studi Empiris Pada Perusahaan Yang Terdaftar Di Bursa Efek Indonesia Periode 2015-2017). In Jurnal Eksplorasi Akuntansi (Vol. 1, Issue 1).

Oentoro, Vannesa Paramitha, A. R. A. (2019). Pengaruh Audit Tenure, Komite Audit Dan Ukuran Perusahaan Terhadap Kualitas Audit (Studi Empiris Pada Perusahaan Food \& Beverage Yang Terdaftar Di BEI Periode 2014-2017). Jurnal Ilmiah Akuntansi Dan Teknologi, 11(2), 1-7.

Purnomo, Listiya Ike, A. J. A. (2019). Pengaruh Fee Audit, Audit Tenure, Rotasi Audit Dan Reputasi Auditor Terhadap Kualitas Audit. Ekopreneur, 1(1), 50-61.

Rahmina, Listya Yuniastuti., A. S. A. (2014). Influence of auditor independence, audit tenure, and audit fee on audit quality of members of capital market accountant forum in Indonesia. Procedia - Social and Behavioral Sciences, 164, 324-331.

Seftianne. (2011). Faktor-Faktor Yang Mempengaruhi Struktur Modal Pada Perusahaan Publik Sektor Manufaktur. Jurnal Bisnis Dan Akuntansi, 13(1), 39 - 56.

Sirait, M. S. (2020). Pengaruh Audit Tenure, Akuntabilitas dan Kompetensi Auditor Terhadap Kualitas Audit Dengan Budaya Organisasi Sebagai Variabel Moderasi. 
Prosiding Seminar Nasional Pakar, 3.

Sugiyono. (2017). Metode Penelitian Kuantitatif, Kualitatif, dan R\&D. Bandung: Alfabeta.

Udayanti, Ni Kadek Sri., A. D. A. (2017). Pengaruh Auditor Switching, Ukuran Perusahaan, Spesialisasi Industri KAP, Dan Client Importance Pada Kualitas Audit. E-Jurnal Akuntansi Universitas Udayana, 20, 1073-1102.

Yadiati, Winwin., A. A. M. (2017). Kualitas Pelaporan Keuangan. Jakarta: Kencana Prenadamedia Group.

Yolanda, Stephanie., Fefri Indra Arza, A. H. (2019). Pengaruh Audit Tenure, Komite Audit Dan Audit Capacity Stress Terhadap Kualitas Audit. Jurnal Eksplorasi Akuntansi, 1(2), 543-555.

\section{Sumber Dari Internet atau Website :}

Kasus KAP (Tanubrata, Sutanto, Fahmi, Bambang \& Rekan selaku auditor laporan keuangan PT Garuda Indonesia (Persero). Diakses pada tanggal (1 Oktober 2020) www.economy.okezone.com.

Laporan Keuangan dan Tahunan Perusahaan tercatat Bursa Efek Indonesia Diakses pada tanggal (25 Juli 2020) www.idx.co.id

Standar Profesional Akuntan Publik Diakses (06 Oktober 2020)_https://iapi.or.id/.

Perusahaan Manufaktur Sektor Industri Dasar dan Kimia Diakses pada tanggal (25 Juli 2020) www.sahamok.com. 